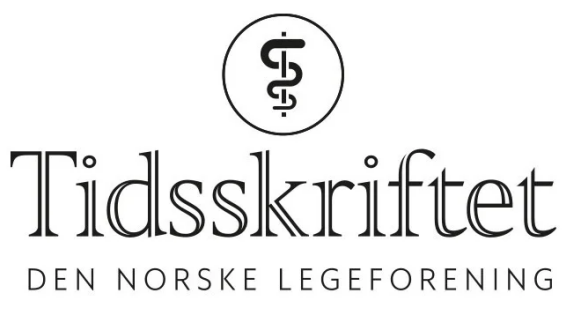

\title{
Depressive symptomer hos hver tredje fødekvinne under pandemien
}

REPORTASJE

\section{CAROLINE ULVIN JOHANSSON}

caroline.ulvin.johansson@tidsskriftet.no Tidsskriftet

Depressive symptomer blant kvinner som har født under covid-19-pandemien, har økt betydelig, ifølge en fersk studie. - Jeg har aldri følt meg så alene som på barselavdelingen, sier småbarnsmor. 


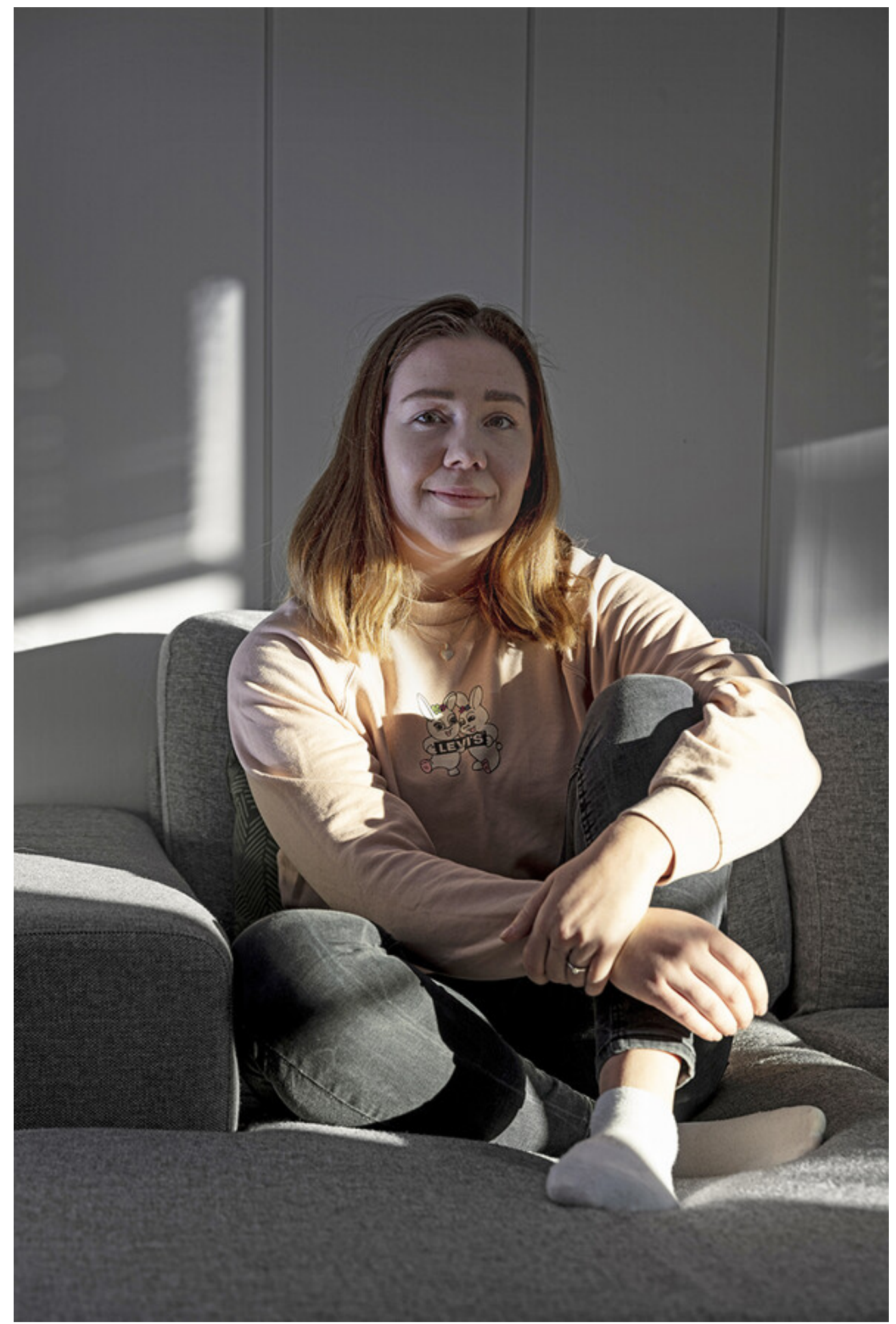

Foto: Christian Tunge

Andrea Bang Hansen er akkurat ferdig med dagens Zoom-forelesninger, samtidig som sønnen Jens leker i bakgrunnen. Selv ett år og ni måneder etter hennes første fødsel er pandemien fremdeles et faktum - og småbarnsmoren har det travelt med å kombinere studier og familieliv med et pågående kjør av forkjølelser, rennende neser og selvtester. Hun hadde aldri sett for seg at koronapandemien skulle trekke ut i en årelang situasjon med smittevern og tiltak.

- Jeg husker jeg stod høygravid 12. mars 2020 og tenkte: Shit, hva gjør jeg nå? Og så husker jeg at alle rundt meg var trøstende og sa: Det er lenge til du skal føde, du trenger ikke tenke på det. Sånn ble det jo ikke i det hele tatt. 
For da Andrea dro til sykehuset for å føde 27. april 2020, måtte hun gå inn og registrere seg helt alene, mens far ventet $\mathrm{i}$ bilen. Og etter å ha våknet fra det som ble et hastekeisersnitt, fikk hun ikke mer enn fem minutter på gangen med far. Han ble sendt hjem og hun ble trillet videre til barselopphold. Helt alene.

\section{"Jeg har aldri følt meg så alene $i$ hele mitt liv»}

- Fordi det var keisersnitt, fikk jeg beskjed om at jeg burde være på sykehuset i fire dager. Men jeg hadde bare lyst til å dra hjem hele tiden. Jeg følte meg så alene. Jeg har aldri følt meg så alene i hele mitt liv.

\section{Nesten én av tre}

Etter nesten to år med pandemi, nedstengninger, restriksjoner og smitteverntiltak er det ingen tvil om at situasjonen virkelig har preget landets gravide.

I en nylig publisert originalartikkel i Tidsskriftet kommer det frem at andelen spedbarnsmødre med høy skår for depressive symptomer var $32 \%$ under pandemien, sammenlignet med 10 \% blant kvinner som fødte ti år tidligere. Det vil si at nesten én av tre kvinner som deltok i undersøkelsen, opplevde psykiske helseplager knyttet til fødsel og barseltid.

- Tallene tyder på at pandemien kan ha bidratt til dårligere psykisk helse hos spedbarnsmødre. Våre funn er i tråd med tall fra internasjonale studier, der flere rapporterer om en betydelig økning av angst- og depresjonssymptomer hos gravide og nybakte mødre under pandemien, sier spesialist i samfunnsmedisin og professor Malin Eberhard-Gran. Hun er prosjektleder for den nye undersøkelsen og jobber ved Nasjonalt senter for kvinnehelseforskning ved Oslo universitetssykehus.

\section{Fikk fem minutter på gangen}

Andrea Bang Hansen er absolutt ikke alene om å ha opplevd psykiske vansker i forbindelse med graviditet, barsel og fødsel. I løpet av de siste årene har vi hørt flere historier i mediene om nybakte mødre med dårlige erfaringer. Mange har opplevd restriksjonene som en stor belastning, og usikkerhet rundt partners tilstedeværelse har ført til protester på sosiale medier under emneknagger som \#jegføderikkealene. Vi har også sett fremveksten av interessegrupper som «Barselopprøret».

Bang Hansen forteller at fødsels- og barselopplevelsen har preget henne mye i ettertid.

- Jeg skjønte det ikke, men jeg tror at jeg allerede på barsel begynte å bli deprimert. Jeg følte meg alene og hadde ikke lyst til å ta noe plass, fordi de som var på jobb hadde dårlig tid, sier hun.

- De ansatte var absolutt gode i jobben sin og omsorgsfulle, men jeg følte på et stress blant dem, legger hun til.

Et av minnene som har festet seg særlig godt hos småbarnsmoren, er det korte møtet hun fikk med samboeren Thomas da hun ble trillet opp på barselavdelingen etter keisersnittoperasjonen. Deres nyfødte sønn lå da til observasjon på nyfødtintensivavdelingen. 


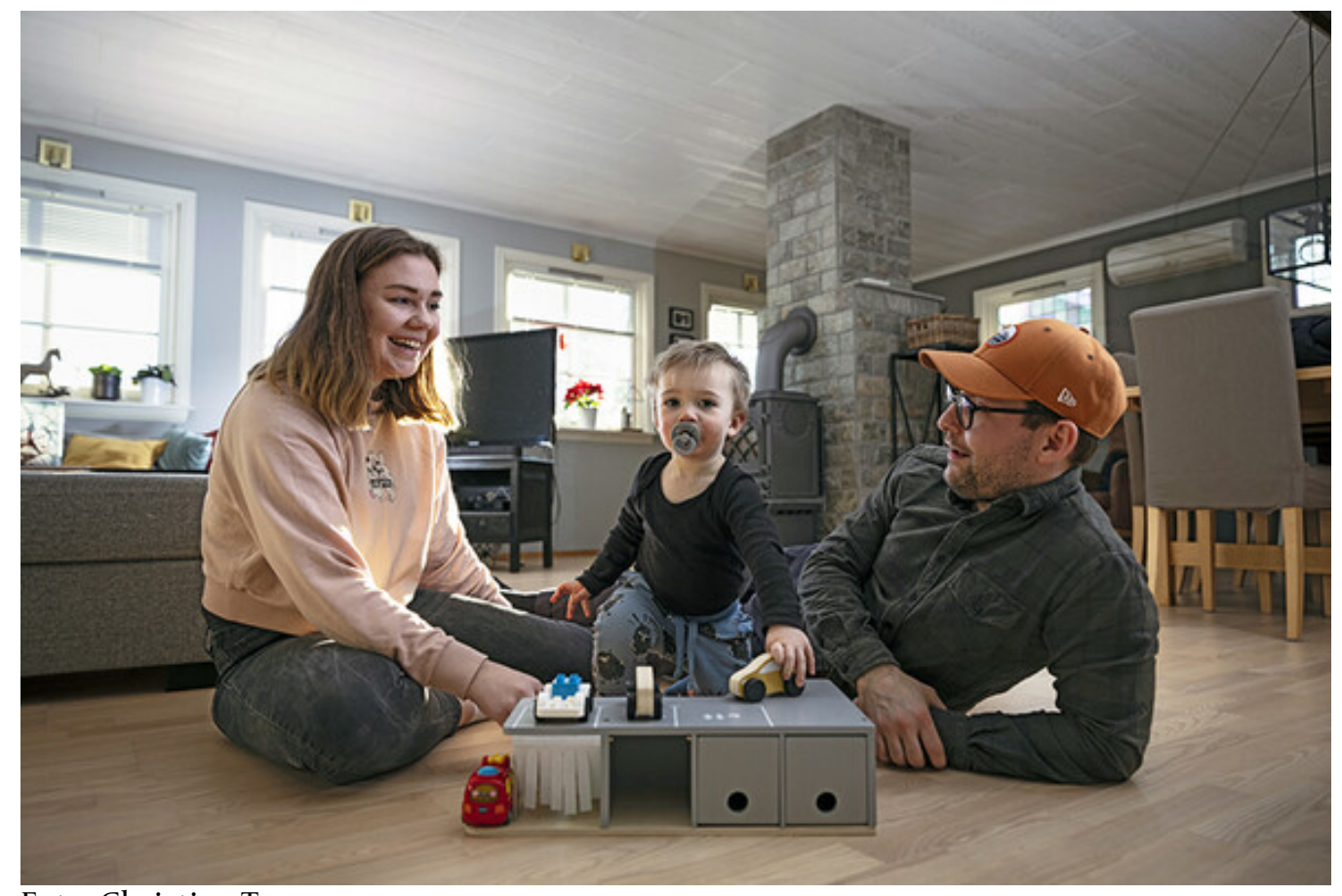

Foto: Christian Tunge

- Jeg fikk møte mannen min i gangen. Han viste meg noen bilder av Jens. Så det første møtet med ungen min var igjennom bilder. Vi fikk fem minutter sammen på gangen, hvor han stod og klemte meg mens jeg lå der i senga. Og så ble han bedt om å dra hjem, og jeg ble trillet inn på barsel uten babyen min, forteller hun.

Det skulle gå et halvt døgn før Bang Hansen fikk se sønnen for første gang.

\section{Isolasjon øker risikoen for depresjon}

Høyt smittetrykk i samfunnet har tidvis ført til at mange gravide og nybakte mødre har blitt mer eller mindre isolert. Dette har bidratt til redusert sosial støtte, ifølge EberhardGran.

- Som ny forelder er sosial støtte ekstremt viktig, og mangel på dette er en veldokumentert risikofaktor for å utvikle fødselsdepresjon, sier hun og understreker at helsestasjoner og flere hjelpeinstanser har hatt svært begrenset tilgjengelighet $\mathrm{i}$ lange perioder.

Dette er noe Bang Hansen kjenner seg igjen i. I tiden etter at hun kom hjem fra sykehuset kjente hun liten glede over det å ha blitt mamma. Hun slet også med amming.

- Jeg følte at jeg ikke hadde fått det til, at det ikke hadde blitt som det skulle. Jeg hadde ikke klart å føde normalt, jeg hadde vært helt alene på barsel. Og nå fikk jeg ikke til ammingen heller.

Hun legger til at hun heller ikke fikk noe hjemmebesøk av jordmor.

\section{Økt pågang}

- Pandemien er på mange måter en oppskrift på å kjenne på psykiske utfordringer. Da den første bølgen kom, formidlet mange gravide og nybakte mødre til oss at de kjente på frykt og usikkerhet, sier Lena Yri Engelsen, som er generalsekretær i Landsforeningen 1001 dager.

«Pandemien er på mange måter en oppskrift på å kjenne på psykiske utfordringer» 
Foreningen jobber med informasjonsbaserte tjenester knyttet til mental helse i den perinatale perioden. Engelsen opplyser at de i 2020 hadde ca. 6 o ooo besøkende på sine nettsider, mot rundt 12 ooo året før.

- Til tross for dette kontaktet en del kvinner oss via sosiale medier. Vi opplevde at henvendelsene var av mer alvorlig karakter enn før. Eksempler er selvmordstanker, søvnproblematikk, depresjoner og traumatiske fødsler, sier Engelsen, som også er en av bidragsyterne til den nye studien.

\section{Urolige kvinner på føden}

Thorbjørn Brook Steen er overlege på fødeavdelingen på Oslo universitetssykehus, Ullevål. Han er ikke overrasket over hovedfunnene i undersøkelsen.

- Det å ha folk og støtte rundt seg er viktig. Mangel på det gir økt risiko for depresjoner. Pandemien har vært med på å fjerne denne tryggheten. Helt konkret ser vi i mye større grad viktigheten av partnere og partners involvering, sier han.

Steen fremholder at de på Ullevål har merket forskjell på kvinnene som har født under pandemien sammenlignet med mer «normale tider».

- Kvinnene er mer redde for ting som eventuelt skal kunne skje, og hvordan dette kan påvirke fødselsopplevelsen deres, som for eksempel uro knyttet til om partner får være til stede.

\section{Fakta om studien}

Totalt 3642 spedbarnsmødre deltok i en nettbasert spørreundersøkelse i april 2021.

Depressive symptomer ble målt i en kortversjon av Edinburgh-skalaen, og

fødselsopplevelse målt med standardiserte spørsmål om graviditet, fødsel og spedbarnstid.

For ti år siden ble deltakerne i Favn om fødselen-studien stilt de samme spørsmålene.

Denne gruppen er brukt som referansepopulasjon.

Kvinnene fra pandemipopulasjonen fikk også spørsmål om pandemien og psykisk helsehjelp.

Funnene er presentert i originalartikkelen «Depressive symptomer og fødselsopplevelse hos spedbarnsmødre under covid-19-pandemien».

Han understreker imidlertid at partner har fått være med på den aktive delen av fødselen gjennom hele pandemien og at besøksrestriksjonene på barselavdeling og observasjonspost har blitt justert underveis i takt med smittetrykket i samfunnet.

Steen trekker videre frem at han tror det er viktig å ha et større fokus på mors mentale helse i et lengre perspektiv, ikke bare i barseltiden.

- Det har vært oppmerksomhet rundt barseldepresjon, men da først og fremst i forbindelse med mors tilknytning til barnet. Mors mentale helse i svangerskapet starter imidlertid allerede ved barnets unnfangelse og varer til barnet er to år. Altså 1 oo1 dager. Å ha et fokus på mors mentale helse gjennom hele denne perioden tenker jeg er viktig for aktivt å forebygge depresjoner, sier han.

På spørsmål om hvilke læringspunkter som har vært mest fremtredende på fødeavdelingen under pandemien, kommer svaret klokkeklart fra Steen:

- Partners enormt viktige involvering i svangerskap, fødsel og barseltid.

Her får han støtte fra Bang Hansen: 


\section{Kostnadskutt, redusert liggetid og ansvarsflytting}

Et annet oppsiktsvekkende funn fra den ferske studien viser at $54 \%$ av de spurte spedbarnsmødrene med psykiske helseplager oppga at de ikke fikk adekvat hjelp. Dette kom noe uventet på Eberhard-Gran.

\section{«Pandemien har nok vert dråpen som fikk begeret til å renne over»}

- Vi ble litt overrasket over at tilgangen på psykisk helsehjelp var såpass dårlig, sier hun. Eberhard-Gran understreker imidlertid at man de siste årene har sett tegn som tyder på at den psykiske helsen til spedbarnsmødre har blitt stadig dårligere.

- Pandemien har nok vært dråpen som fikk begeret til å renne over. Det vil si at pandemien har avdekket en fra før av dårlig oppfølging av psykisk helse hos nye mødre, sier hun.

Eberhard-Gran understreker at man på sykehusene i mange år har forsøkt å kutte i kostnader og løse kapasitetsproblemer ved å redusere liggetid og behandle flere pasienter poliklinisk.

- Ansvaret for nye mødre og spedbarn har dermed i stor grad blitt overført fra sykehusene til kommunene. Utviklingen er svært betenkelig, da de fleste kommuner fortsatt mangler nødvendig kompetanse, tid og ressurser til å overta dette ansvaret, sier samfunnsmedisineren.

\section{Nødvendig å spørre}

Tilbake hos Bang Hansen forteller småbarnsmoren at hun ble henvist til en lokal instans i kommunen etter seksukerskontrollen.

- Jeg ble henvist til noe som heter Familiehuset. Der ble jeg tilbudt samtaleterapi, men jeg følte ikke egentlig at det hjalp så veldig, forteller hun.

På spørsmål om hva vi som samfunn bør gjøre for å forebygge depressive symptomer hos barselkvinner, trekker Eberhard-Gran frem at vi må bli flinkere til å spørre.

- Det er nødvendig å spørre systematisk om psykisk helsetilstand, og ikke bare fysisk. Helsepersonell bør få mer kunnskap om de spesielle mentale utfordringene som forekommer i perinatalperioden, sier hun.

- Vi må også få flere tilbud og mer kunnskap om hvordan vi skal forbedre organiseringen av helsetjenester og henvisningspraksis, legger samfunnsmedisineren til.

For Bang Hansen går det heldigvis bedre i dag.

- Jeg har det bedre. Tiden har hjulpet, og Jens har blitt større. Men det har tatt lang tid, og jeg kjenner at jeg sliter med det enda, forteller hun.

- Er du redd for å bli gravid igjen?

- Ikke direkte. Jeg er veldig sulten på en annen opplevelse. En opplevelse hvor jeg føler meg mindre alene og kan være mer glad, avslutter hun.

Publisert: 4. februar 2022. Tidsskr Nor Legeforen. DOI: 10.4045/tidsskr.22.0070

(C) Tidsskrift for Den norske legeforening 2023. Lastet ned fra tidsskriftet.no 26. april 2023. 